\title{
Participatory Process in Public Organisations for Regional Development: the Case of Latvia
}

\author{
Inga Jekabsone \\ "RISEBA" University College of Business, Arts and Technology \\ 3 Meza Street, Riga, LV-1048, Latvia \\ cross $^{\text {refhttp://dx.doi.org/10.5755/j01.ppaa.18.3.24151 }}$
}

\begin{abstract}
In the case of Latvia, formal requirements of involvement of citizens in decisionmaking processes at national, regional and local are defined in different legal acts. During the preparation of planning documents, some municipalities and public institutions develop individual approaches to insure productive dialogue with stakeholders. Taking into account ongoing administrative-territorial reform in Latvia, there is a need for more inclusive models of citizens' participation in the decision-making process at the regional level. The paper aims to analyse the approaches of involvement of stakeholders in decision-making processes in the context of regional development. In order to achieve the aim, the following research methods have been used: scientific literature studies, statistical data analysis, expert survey. Main results and conclusions of the paper: the research showed that in the case of Latvia, existing approaches of public institutions could be defined rather as formal or engagement partnership towards fulfilment of requirements of legal acts. In order to proceed towards to co-responsible cooperation model, public organisations should use ICT opportunities, develop a permanent cooperation model, cultivate targeted strategic communication and include the principles of participatory budgeting in the budget planning process.
\end{abstract}

Keywords: stakeholders' involvement, regional development, municipalities, participatory budgeting

Raktažodžiai: suinteresuotujų šaliu ịtraukimas, regionu plètra, savivaldybès, dalyvavimo biudžeto sudarymas

\section{Introduction}

In the last decades, public administration theorists indicate the concepts of new public governance and new public services (Denhardt and Denhardt 2000; Osborne 2010). The idea of new public governance is based on "the concept of democracy and citizen participation as an essential precondition for effective institutional performance" (Suebvises 2018). It is argued that "horizontal relationships between public administrators and their fellow citizens are necessary to increase citizens' satisfaction with public administration" (Denhardt and Denhardt 2000).

Public administration in this context of citizen/stakeholder participation is defined as the interaction of citizens/ stakeholders and public administrators and direct participation of citizens/ stakeholders in public policy decisions, public service delivery, and quality improvement processes (Callahan 2007; Roberts 2004).

In brief,

stakeholder participation refers to the inclusion of various stakeholders that can affect, or are affected by, the results of policy-making and decision-making processes. In general, several institutions and actors are invited to participate in such processes, for instance, civil society organisations/NGOs, business representatives, social partners (i.e. trade unions, chambers of commerce, etc.), sub-national authorities, academia and individual citizens. 
Academic studies and policy statements lauding the benefits of participatory policy processes have made participation one of the most widely used concepts in development politics (Reed, 2008; Henning et al., 2019). Beyond normative claims, pragmatic claims focus on "higher quality and sustainability of political decisions arising from participatory policy processes" (Blackstock et al. 2007).

One critique is that "stakeholder participation has not been meaningfully implemented by governments, with groups of citizens still being excluded from political decision-making or their involvement being limited to pure consultation" (Siebold 2007). The failure of participatory policy processes is explained by the fact that "participating stakeholders lack the capacity and technical knowledge to make sound political decisions" (Hage et al. 2010).

Additionally, many policy-makers have difficulties to use up-to-date ICT opportunities. Jassen and Helbing (2018) admitted that "advances in ICTs continue to have an impact on the ways that policy-makers and citizens engage with each other throughout the policy-making process". For example, the latest trends are to explore gamification elements in the public sector through the Octalysis model, using specific game technologies like augmented reality and internet of things (Yfantis and Tseles 2017). It is widely recognized that "advanced ICTs have impacted the ways that policy-makers and citizens engage in the policy-making process" (Charalabidis and Koussouris 2012).

Stakeholders' participation is vital at all levels. Suebvises (2018) admitted that "state, regional and local governments have to be interested not only in improving their performance but also in maintaining public confidence in the implementation of decisions". In this context, stakeholders' participation is an essential resource in terms of decision-making processes.

In case of Latvia, public authorities at different levels face with challenges how to ensure stakeholders' participation in context low trust in public administration, lack of possibilities to participate in decision-making processes for some social groups, as well as rather unpopular ongoing administrative-territorial reform.

Therefore, the paper analyses the approaches of involvement of stakeholders in decisionmaking processes in the context of regional development.

The tasks are as follows:

1. To review a theoretical background on participatory policy for regional development;

2. To assess empirical research on different approaches of public administrators in the involvement of stakeholders in the decision-making process for regional development in EU;

3. To provide recommendations for public administrators on the active involvement of stakeholders in the decision-making process in Latvia.

In order to achieve the aim, the following research methods have been used: scientific literature studies, statistical data analysis, and expert survey.

The novelty of this research includes the structuration of different approaches of Latvian public administrators in stakeholders' involvement in decision-making processes using a theoretical model on stakeholders' involvement.

\section{Methodology}

In the beginning of the research, the theoretical background on the active involvement of stakeholders in public administration was reviewed. Then, based on the conceptual model on stakeholders' involvement in the decision-making processes in public administration, the structure of the questionnaire was prepared for an expert survey. During the survey, seven experts were interviewed according to the prepared questionnaire (semi-structured interview). Research period: March - June 2019. The experts were selected by taking into account their professional expertise in public administration and involvement of stakeholders in decision-making processes covering national, regional and local level. The experts represented national authorities (Ministry of Environmental Protection and Regional Development), regional authorities (Planning Regions) and 
local (authorities (municipalities). In this paper, a part of the survey results revealed according to their relation to the suitable approaches of public administrators towards more inclusive participatory process.

\section{Findings}

In this section, the effective practice of involvement of stakeholders in public administration in the context of regional development would be reviewed. Furthermore, the case of Latvia would be analysed.

\section{Review of scientific literature studies: development of theoretical model on the active involvement of stakeholders in public administration for regional development}

The implementation of regional public management requires the participation and support of the stakeholders, and stakeholders' participation has become an essential feature in public management all over the world.

In order to ensure the active involvement of stakeholders in public administration, it is crucial to evaluate the current situation with the engagement of society in decision-making processes. One of the approaches is to use the seven-point scale developed by the experts of the Council of Europe.

Minimal engagement means that public administrators consult society on a few topics, but mostly no feedback is provided. In turn, formal partnership is a form of formal relationship with several citizens and organisations outside the public organisation. Some forms or approaches for consultations are developed, mostly to follow requirements of normative acts. More developed form is an engaged partnership when citizens or non-governmental institutions have a real influence on agenda and decision-making processes. However, ultimately, the public administrators retain the decisive influence. Next engagement levels include more effective relationship forms:

- Co-governance means that society has a possibility to participate in the strategic planning of a service or process;

- Co-management refers to a situation where citizens and civil organisations work alongside each other to coordinate the delivery of a service or process;

- Co-production refers to a situation where citizens produce, at least in part, the services they use themselves.

At the end, co-responsibility represents the situation where the elements outlined before (co-governance, co-management, co-production) are combined across a whole sector, for example within the culture system in a municipality, or development of support programmes for research (Bloomfield 2012).

Often, stakeholders' participation in regional public management is mainly related to citizen participation in the formulation and implementation of public policy, citizen participation in public goods provision and governance of local communities. World Bank, an organisation that has a long history and intensive experience with stakeholders' engagement, has defined the primary stakeholders' engagement mechanisms:

- Consultation;

- Grievance redress;

- Collecting, recording, and reporting on inputs received from beneficiaries;

- Capacity building for engagement;

- Citizen/community collaboration on planning and/or execution of a policy, program or project;

- Citizen monitoring, evaluation and oversight;

- Empowering citizens/communities with resources and decision-making power (World Bank, 2014).

All these mechanisms could be easily adapted to the public administration at local, regional or national level. However, it is crucial how to ensure the implementation of these mechanisms to 
overcome the challenges of low trust in public administration, exclusion of some social groups and different level of awareness and digital skills.

Table 1. The participatory process in public administration.

\begin{tabular}{|c|c|c|}
\hline Positive Behaviour and Relationship & $\begin{array}{c}\text { Change Positive Operational } \\
\text { Change } \\
\end{array}$ & Positive Institutional Change \\
\hline $\begin{array}{l}\text { - Knowledge of rights and obligations } \\
\text { - Self-confidence to voice concerns } \\
\text { - } \text { Responsiveness to citizens } \\
\text { demands/needs } \\
\text { - Willingness to participate and } \\
\text { collaborate } \\
\text { - Trust between citizens and state } \\
\text { actors }\end{array}$ & $\begin{array}{l}\text { - Citizens' priorities guide } \\
\text { operational choices } \\
\text { - Efficiency in responding to } \\
\text { citizens' needs: } \\
\checkmark \text { Better targeted budget allocations } \\
\checkmark \text { Improved project and service } \\
\text { delivery management } \\
\checkmark \text { Improved service quality }\end{array}$ & $\begin{array}{l}\text { - Improved policy framework } \\
\text { - Transparency and } \\
\text { accountability } \\
\text { - Institutional mechanisms for } \\
\text { citizens' voice within country } \\
\text { systems } \\
\text { - Inclusive and cohesive societies }\end{array}$ \\
\hline
\end{tabular}

Source: adapted from World Bank 2018

The researchers (e.g. Janowski et al. 2018; Gallo et al. 2018) have analysed the positive correlation between effective participatory process and behavioural, operational and institutional changes. Institutions that involves stakeholders in different stages of policy planning, especially in the decision-making process, experience an overall higher level of trust of citizens. In the same way, the bureaucratic processes tend to improve, implementing e-governance and other mechanisms that enhance overall public management framework.

Based on the theoretical research, the theoretical model on the active involvement of stakeholders in public administration for regional development was developed.

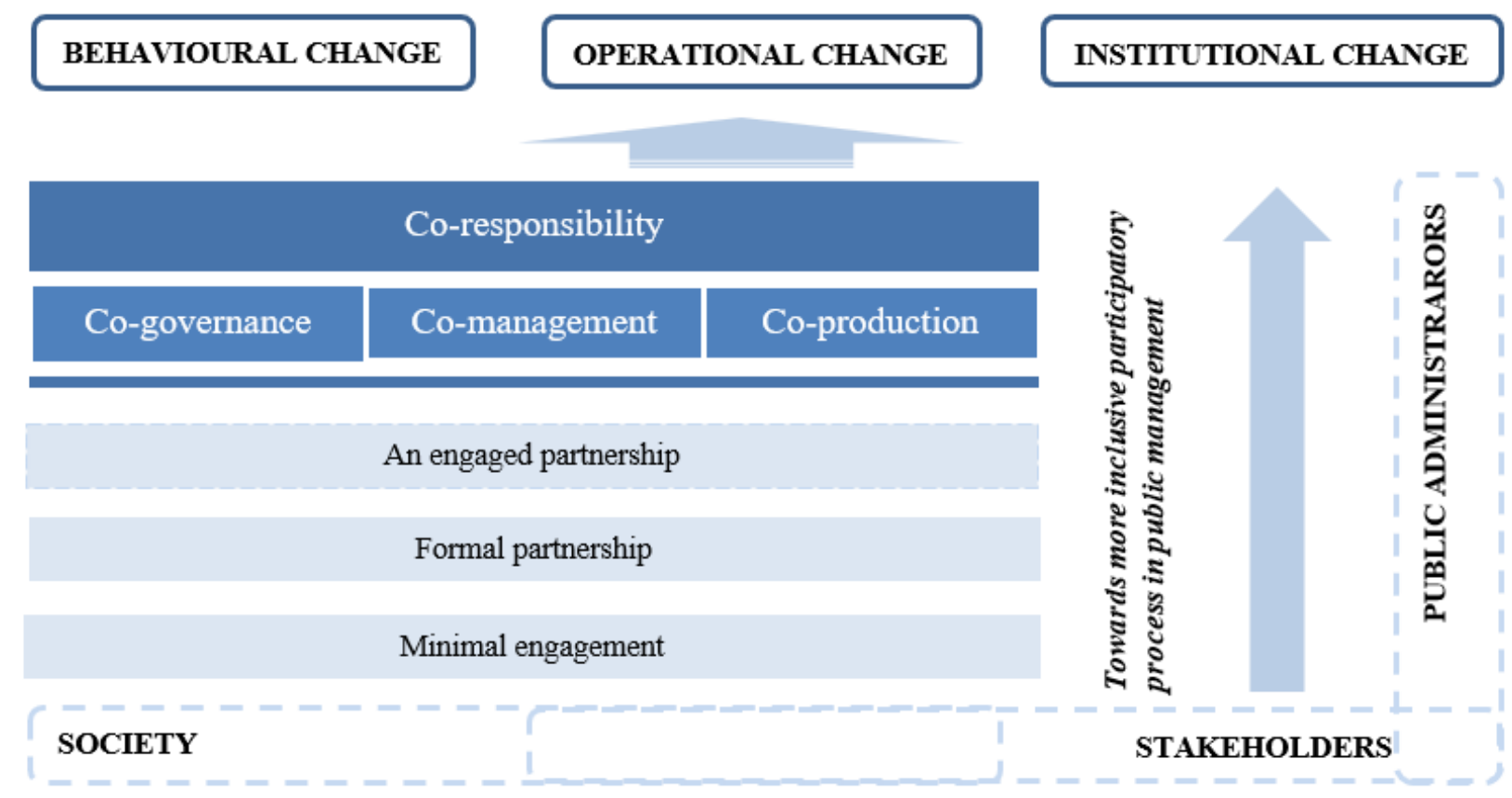

Fig. 1. Theoretical model on active involvement of stakeholders in public administration for regional development.

Source: Author's illustration based on Bloomfield 2012; World Bank 2018; Janowski et. al 2018.

In this theoretical model interaction among society, stakeholders and public administrators are reproduced towards more inclusive participatory process in public management. According to this theoretical model, the structure for the expert survey was developed. 


\section{Possibilities of involvement of stakeholders in the decision-making at the regional level in}

Latvia

In the case of Latvia, the Planning Region Development Council formed the planning regions. The planning regions are Kurzeme Planning Region, Latgale Planning Region, Riga Planning Region, Vidzeme Planning Region and Zemgale Planning Region (see Fig. 2.) (Latvijas Vēstnesis 2004).

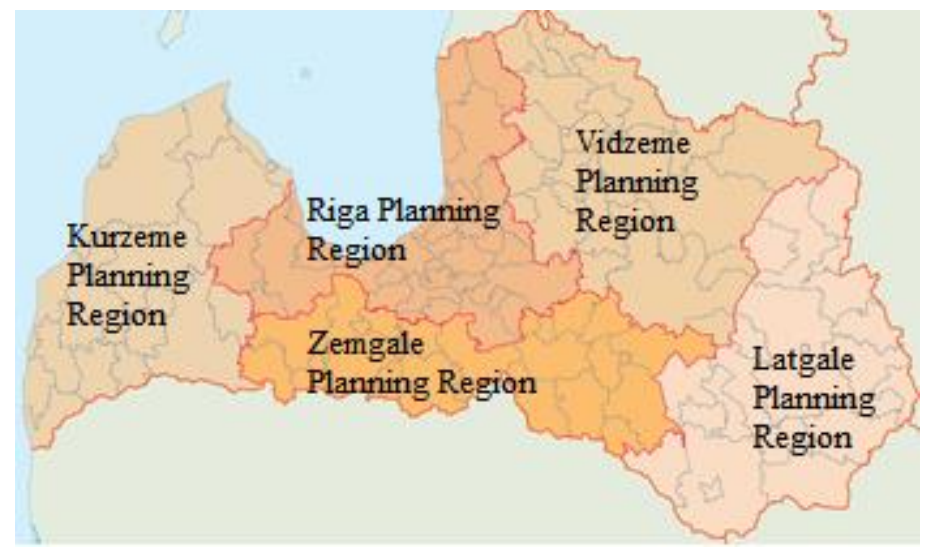

Fig. 2. Planning Regions of Latvia.

Source: author's illustration

The competence of the planning region is to ensure planning, co-ordination of regional development, co-operation between local governments and other public administration institutions, including:

- Identify the basic principles, objectives and priorities for the long-term development of the region;

- In cooperation with local governments and public administration institutions, develop long-term and medium-term development planning documents (spatial plan and development program) and manage and monitor their implementation;

- To prepare opinions on the conformity of national development planning documents with the interests of the planning region;

- Evaluate and provide opinions on regional and local level development planning documents mutual coherence and compliance with regulatory requirements;

- To evaluate and provide opinions on project applications of local governments or private persons for receiving regional development state aid;

- Develop and implement projects within regional development support measures (Ministry of Environmental Protection and Regional Development of the Republic of Latvia, 2019).

Analysis of planning documents showed that innovative government and public participation is one of the horizontal priorities (Cross-sectoral Coordination Centre of the Republic of Latvia 2010). In Latvia 2030 is defined that "within the context of transformation of democratic institutions the most significant challenge for the government of Latvia is the ability to find new co-operation and participation mechanisms which would establish and multiply the social capital of the society" (Cross-sectoral Coordination Centre of Republic of Latvia 2010).

However, the public sector still faces challenges for successful participatory process. According to the recent results of Standard Eurobarometer (November 2018), only $32 \%$ of citizens of Latvia tend to trust public authorities, while $56 \%$ tend not to trust them (in the same time, in Estonia results are respectively $49 \%$ and $40 \%$ ) (European Commission 2018).

In the case of Latvia, formal participatory forms in policy planning are defined in legislation, e.g. public participation procedure in the development planning process (Latvijas Vēstnesis 2009a), regulations on the public accounts (Latvijas Vēstnesis 2010), involvement in development for documentation that is being considered by the Cabinet of Ministers (Latvijas Vēstnesis 2009b). 
According to the Cabinet of Ministers Regulations No. 970, "Society participation in the development planning process" public participation is possible in the following in the stages of the development planning process:

1. initiating the development planning process;

2. development planning document;

3. in the decision-making process, in accordance with the procedures laid down by the decision-making body;

4. implementation of the development planning document;

5. monitoring and evaluating the implementation of development planning document;

6. Update of the development planning document (Latvijas Vēstnesis 2009b).

Ministry of Environmental Protection and Regional Development is responsible ministry for regional development and e-governance. The ministry has defined state organizational model for the governance of information and communication technologies where data democracy, citizen engagement and data-driven innovation are main priorities (Ministry of Environmental Protection and Regional Development of the Republic of Latvia, 2015). In turn, State Chancellery - responsible authority for the implementation of participatory process in public administration. In recent studies, State Chancellery has defined several challenges:

- lack of awareness in society about participation and its importance;

- lack of time and other resources;

- lack of information on participation opportunities;

- the inactivity and disbelief of the society in its ability to influence the state and local governments institutions;

- lack of activity and empathy in state and municipal institutions;

- participatory process is perceived as an additional burden;

- lack of skills to listen and find compromise;

- lack of political will to involve society in decision-making (State Chancellery of the Republic of Latvia, 2018).

The next section presents the results of expert survey.

\section{Towards more inclusive participatory process in Latvia}

The results of semi-structural interview with experts of regional development exposed several directions towards more inclusive participatory process in public administration:

1. Targeted strategic communication - there should be paid attention to how to present information to different target audiences as well as what narratives to use in building the image of organisation;

2. ICT possibilities towards more effective and interactive communication with citizens - use different digital tools to ensure effective e-governance and e-services;

3. Individual cooperation model (network) with stakeholders based on transparent structure and roles - public authorities should build their model of interaction with citizens, e.g. Local support group, convention, council, forums according to the needs and structure of stakeholders;

4. Participatory budgeting - public authorities should develop their approach in the inclusion of stakeholders in the budgeting process.

Experts admitted that systematic activities within these directions would provide the realisation of co-responsibility approach in public management. The experts offered good practices of public organisations how they ensure the involvement of stakeholders in decision-making processes. Fig. 3 presents some examples of good practice.

During the last years, public actors use different possibilities of ICT on ensuring citizens' engagement, for example improving public services, providing platforms how to engage society (complaints, suggestions, latest information on topicalities, etc.). Besides, public actors have started to implement the principles of participatory budgeting, e.g. some municipalities allocate special funds 
for NGOs, organise project calls, set priorities for some municipal budget according to citizens' preferences (for culture). Many civic organisations also have developed platforms for regular communication with society (councils, local support groups, advisors, etc.).

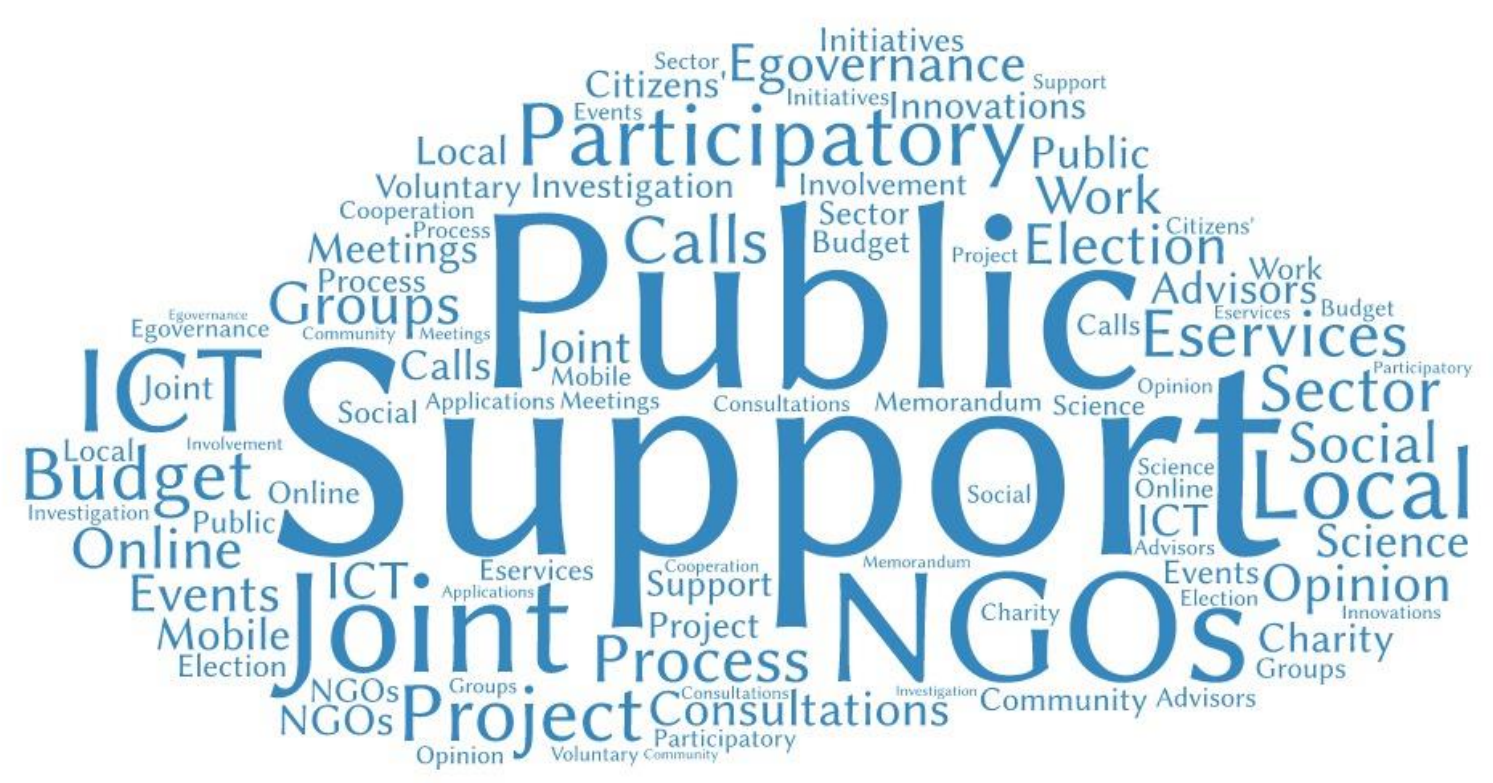

Fig. 3. Approaches of public institutions in Latvia in the participatory process.

Source: author's illustration based on expert survey and publicly available information

Besides, the experts provided opinion that mostly in Latvia public institutions' cooperation model with stakeholders could be described as "formal partnership" or "engaged partnership" according to the seven-point scale developed by the experts of Council of Europe (Bloomfield 2012). However, experts admitted that the overall situation in the development of productive dialogue with stakeholders improves abandoning formal approaches. Notably, the situation improves thank to the development of e-governance, successful communication campaigns and more active participation of citizens in civic organisations.

\section{Conclusions}

1. Taking into account that citizen participation achieves democratic and scientific public management, every public organisation should formulate its policy regarding involvement of stakeholders in decision-making and policy processes avoiding formal approach only to fulfil the requirements of national legal acts. It can be done by strong commitment of management to move forward to co-responsible governance model fixing principles and activities in external in internal normative acts.

2. According to the opinion of the regional development experts, in case of Latvia, the cooperation model of public institutions with citizens could be described as formal or engagement partnership. These cooperation models include mostly formal fulfilment of requirements stated in the legal acts as well as some fragmented initiatives within the framework of international projects.

3. The results of expert survey analysis showed the main directions in public management are towards inclusive, participatory process, which includes targeted strategic communication, use ICT opportunities towards effective e-governance, development of individual permanent cooperation model with stakeholders, as well as involvement of principles of participatory budgeting in the budgeting process.

4. Further research requires to analyse the possibilities of how the public organisation in Latvia could move forward to co-responsible cooperation model within identified directions towards an inclusive, participatory process that would promote regional development. 


\section{References}

1. Blackstock, K., Kelly, G., Horsey, B. Developing and Applying a Framework to Evaluate Participatory Research for Sustainability. Ecological Economics, 2007, Vol. 60, p.726-742.

2. Bloomfield, J. Together Report, 2012. http://www.forumdascidades.pt/sites/default/files/ Projetos/ together_final_report_rev.pdf [2019-09-06].

3. Cabinet of Ministers of Republic of Latvia Regulations No.300 "Order of the Cabinet of Ministers". Latvijas Vēstnesis, 07.04.2009., No 58.

4. Cabinet of Ministers of Republic of Latvia Regulations No.413 "Provisions on annual public accounts". Latvijas Vèstnesis, 05.05.2010., No 76.

5. Cabinet of Ministers of Republic of Latvia Regulations No.970 "Procedures for Public Participation in the Development Planning Process". Latvijas Véstnesis, 25.08.2009., No 141.

6. Callahan, K. Citizen Participation: Models and Methods. Journal of Public Administration, 2007, Vol.30, p. 1179-1196.

7. Charalabidis, Y., Koussouris, S. Empowering Open and Collaborative Governance. Technologies and Methods for Online Citizen Engagement in Public Policy Making. Springer, 2012, 295 p.

8. Cross-sectoral Coordination Centre of Republic of Latvia. Sustainable Development Strategy of Latvia 2030. https://www.pkc.gov.lv/sites/default/files/inline-files/LIAS_2030_en_1.pdf [201909-06].

9. Denhardt, R.B., Denhardt, J.V. The New Public Service: Serving Rather than Steering. Public Administration Review, November/December 2000, Vol.60, No 6, p.549-559.

10. European Commission. Standard Eurobarometer 2018: National Report of Estonia. http://ec.europa.eu/commfrontoffice/publicopinion/index.cfm/Survey/getSurveyDetail/instrume nts/STANDARD/surveyKy/2215 [2019-09-06].

11. Gallo, M., Pezdevšek Malovrh, S., Laktić, T., De Meo, I., Paletto, A. Collaboration and Conflicts between Stakeholders in Drafting the Natura 2000 Management Programme (2015-2020) in Slovenia. Journal for Nature Conservation, 2018, Vol.42, p.36-44.

12. Hage, M., Leroy, P., Petersen, A.C. Stakeholder Participation in Environmental Knowledge Production. Futures, 2010, Vol. 42, p. 254-264.

13. Henning, C., Aßmann, C., Hedtrich, J., Ehrenfels, J., Krampe, E. What Drives Participatory Policy Processes: Grassroot Activities, Scientific Knowledge or Donor Money? - A comparative policy network approach. Social Networks, 2019, Vol. 58, p.78-104.

14. Janowski, T., Estevez, E., Baguma, R. Platform Governance for Sustainable Development: Reshaping Citizen-administration Relationships in the Digital Age. Government Information Quarterly, 2018, Vol. 35, No 4, Supplement, p.1-16.

15. Ministry of Environmental Protection and Regional Development of Republic of Latvia (VARAM). Planning Regions, 2019. http://www.varam.gov.lv/lat/darbibas_veidi/reg_att/pl_reg/ ?doc=13637 [2019-09-06].

16. Ministry of Environmental Protection and Regional Development of Republic of Latvia. Concept "State Organizational Model for Governance of Information and Communication Technologies", 2015. http://polsis.mk.gov.lv/documents/4212 [2019-09-06].

17. Osborne, S.P. The New Public Governance: Emerging Perspectives on the Theory and Practice of Public Governance Routledge, Oxon, 2010.

18. Pisano, U., Lange, L.K., Lepuschitzand, K., Berger, G. The Role of Stakeholder Participation in European Sustainable Development Policies and Strategies. ESDN Quarterly Report No 39, 2015. https://www.sd-network.eu/quarterly\%20reports/report\%20files/pdf/2015-DecemberThe_role_of_stakeholder_participation_in_European_sustainable_development_policies_and_st rategies.pdf [2019-09-06].

19. Reed, M.S. Stakeholder Participation for Environmental Management: a Literature Review. Biological Conservation, 2008, Vol.141, p. 2417-2431.

20. Regional Development Law, Latvijas Vēstnesis, 53 (2628), 23.04.2004. 
21. Roberts, N. Public Deliberation in an Age of Direct Citizen Participation. American Review of Public Administration, 2004, Vol. 34, No 4, p. 315-353.

22. Siebold, T. Participation in PRS Processes - a Review of the International Debate. Stakeholder Participation in Poverty Reduction Duisburg. INEF Report, 2007, vol. 86, p.13-30.

23. State Chancellery of Republic of Latvia. How to Build More Effective Public Participation in the Work of State and Municipal Institutions? 2018 https://www.mk.gov.lv/sites/default/files /attachments/2_i_dala_janis_citskovskis.pdf [2019-09-06].

24. Suebvises, P. Social Capital, Citizen Participation in Public Administration, and Public Sector Performance in Thailand. World Development, 2018, Vol. 109, p. 236-248.

25. World Bank. Engaging Citizens for Better Development, 2018. Independent Evaluation Group, Washington, DC: World Bank. e: https://www.ecgnet.org/sites/default/files/Engaging_Citizens_ for_Better_Development_Results_FullReport.pdf [2019-09-06].

26. World Bank Group. Strategic Framework for Mainstreaming Citizen Engagement in World Bank Group Operations: Engaging with Citizens for Improved Results, 2014. Washington, DC: World Bank Group. http://documents.worldbank.org/curated/en/266371468124780089/ Strategicframework-for-mainstreamingcitizen-engagement-in-World-Bank-Group-operations-engagingwith-citizens-for-improved-results [2019-09-06].

27. Yfantis, V., Tseles, D. Exploring Gamification in the Public Sector through the Octalysis Conceptual Model. eRA-12th International Scientific Conference, Proceedings, 2017, p. 78-91.

Inga Jekabsone

\section{Visuomenès įtraukties procesas regionų plètros valdyme: Latvijos atvejis}

\section{Santrauka}

Pastaraisiais metais daugeja tyrimų ir politinių diskusijų dél piliečių itraukimo ị sprendimų priëmimo procesą siekiant darnaus vystymosi tikslų. Tyrejai ir politikos formuotojai plètoja skirtingus metodus, kaip įtraukti suinteresuotąsias šalis ị viešąji valdymą. Dažnai šie požiūriai yra tik formalūs, todèl piliečiai savęs su priimtais sprendimais nesieja.

Latvijoje dažniausiai taikomi tik formalūs piliečių įtraukties reikalavimai, priimant sprendimus nacionaliniu, regioniniu ir vietos lygmeniu. Minètieji reikalavimai yra apibrěžti skirtinguose teisès aktuose. Rengdamos planavimo dokumentus, kai kurios savivaldybès ir viešosios įstaigos naudoj platesnị požiūrị ị efektyvų dialogą su suinteresuotosiomis šalimis. Latvijoje vykstanti administraciné teritorine reforma reikalauja taikyti ịtraukius piliečių dalyvavimo sprendimų prièmimo procese būdus.

Šio straipsnio tikslas yra išanalizuoti metodus, pritaikomus suinteresuotujų šalių ịtraukimui ị sprendimų priemimo procesus regioninès plètros kontekste.

Straipsnyje buvo analizuoti šie uždaviniai:

1. Visuomenès ịtraukties ị regioninès plètros politika ir jos teoriniai pagrindai;

2. İvertinti ịvairių viešojo administravimo institucijų požiūrio ì suinteresuotujų šalių dalyvavimą priimant sprendimus dèl regioninès plètros ES empirinius tyrimus;

3. Pateiktos rekomendacijos viešojo administravimo atstovams kaip veiksmingai įtraukti suinteresuotąsias šalis ị sprendimų prièmimo procesą Latvijoje.

Tikslui pasiekti buvo naudojami šie tyrimo metodai: mokslinès literatūros studijos, statistinių duomenų analizè, ekspertų apklausa.

Pagrindiniai darbo rezultatai ir išvados: tyrimas parodè, kad ES politikos formuotojai, taikydami ịvairius metodus veiksmingiau ịtraukia piliečius ir suinteresuotąsias šalis ị sprendimų prièmimą. Rezultatai atskleidè, kad metodai būna labai ịvairūs, tačiau veiksmingiausi pasirodè tie, kurie buvo kūrybiški bei interaktyvūs. Juos galima vadinti gerosios patirties pavyzdžiais. Latvijoje 
dažnai yra taikomas formalus požiūris, kuris tik siekia patenkinti minimalius teisès aktų reikalavimus. Tačiau pasitaikė ir priešingų sprendimų, tais atvejais valstybès tarnautojai rodė novatorišką požiūrị i veiksmingo dialogo su piliečiais plètrą.

Inga Jekabsone - $\mathrm{PhD}$, researcher at the University of Latvia and assistant professor at RISEBA University of Business, Arts and Technology.

email: jekabsone_inga@inox.lv

Inga Jekabsone - $\mathrm{PhD}$, tyrèja Latvijos universitete ir assist. profesore "RISEBA" Verslo, menų ir technologijų Universitete.

email: jekabsone inga@inox.lv 